\title{
PENDIDIKAN KESEHATAN BAGI PARA PELAJAR DI KOTA KENDARI
}

Nur Illiyyin Akib, Muh. Arba, Suryani, Henny Kasmawati, Yamin, Ruslin, Sunandar Ihsan Fakultas Farmasi, Universitas Halu Oleo, Kendari

$$
\text { E-mail : nurilliyyin@ymail.com }
$$

\begin{abstract}
Abstrak: Telah dilaksanakan kegiatan Pengabdian pada Masyarakat terintegrasi KKN-Tematik berupa pendidikan kesehatan bagi para pelajar di Kota Kendari. Kegiatan ini bertujuan untuk meningkatkan pemahaman tentang kesehatan bagi para pelajar. Kegiatan ini dilaksanakan di beberapa sekolah di Kota Kendari. Kegiatan dilaksanakan mulai Agustus hingga Oktober 2018. Pelaksanaan kegiatan terdiri atas penyuluhan keamanan pangan, obat, dan kosmetika oleh dosen terhadap pelajar SMAN 11 Kendari, SMA Muhammadiyah Kendari, SMKN 6 Kendari, dan SMK Satria Kendari; penyuluhan penggunaan obat bagi pelajar SMPN 05 Kendari; pengenalan profesi apoteker dan penyuluhan Pola Hidup Bersih dan Sehat (PHBS) bagi pelajar SDN 02 Baruga dan SDN 03 Poasia; serta penyebaran informasi melalui media cetak. Penyuluhan dilakukan dengan metode ceramah, praktek, tanya jawab. Media cetak yang digunakan adalah leaflet. Kegiatan ini berhasil meningkatkan pemahaman tentang kesehatan bagi para pelajar di Kota Kendari.
\end{abstract}

Kata Kunci: Pendidikan Kesehatan, Pelajar, Penyuluhan, Obat, Kota Kendari.

\section{A. PENDAHULUAN}

Visi Kementerian Kesehatan Republik Indonesia yang tertuang dalam Keputusan Kementrian Kesehatan Republik Indonesia adalah mewujudkan masyarakat sehat yang mandiri dan berkeadilan. Masyarakat sehat dan mandiri adalah suatu kondisi masyarakat Indonesia menyadari, mau dan mampu mengenali, mencegah, dan mengatasi permasalahan kesehatan yang dihadapi. Sehingga dapat bebas dari gangguan kesehatan baik yang disebabkan karena penyakit termasuk gangguan kesehatan akibat bencana, lingkungan, dan perilaku yang tidak didukung untuk hidup sehat.
Salah satu metode yang dilakukan dalam rangka mewujudkan visi mewujudkan masyarakat sehat melaului promosi kesehatan. Promosi kesehatan di Indonesia adalah upaya untuk meningkatkan kemampuan masyarakat melalui pembelajaran dari, oleh, untuk, dan bersama masyarakat. Promosi kesehatan agar masyarakat dapat menolong dirinya sendiri serta mengembangkan kegiatan yang bersumber daya masyarakat, sesuai sosial budaya setempat dan didukung oleh kebijakan publik yang berwawasan kesehatan.

Salah satu wujud dari kegiatan promosi kesehatan adalah melalui kegiatan 
pemberdayaan masyarakat melalui komunikasi, informasi, dan edukasi mengenai pangan, obat, dan kosmetika. Melalui kegiatan sosialisasi pemberdayaan melalui komunikasi, informasi, dan edukasi ini meningkatkan kesadaran dan pengetahuan masyarakat tentang produk obat dan makanan yang berkualitas baik. Juga memenuhi persyaratan keamanan, mutu dan manfaat serta dapat meningkatkan pemahaman masyarakat dalam memilih obat, obat tradisional, kosmetika, dan makanan yang konsumsi atau gunakan sehari-hari. Informasi yang diperoleh tersebut dapat diteruskan kepada masyarakat di lingkungan masing-masing.

Pemahaman masyarakat terhadap keamanan pangan, obat dan kosmetik harus dimulai dari usia dini. Usia remaja merupakan usia yang labil dan keinginan untuk mencoba hal baru yang tinggi. Oleh karena itu perlu dilakukan peningkatan pemahaman kepada remaja khususnya siswa SMU/SMK di Kota Kendari tentang keamanan dalam pemilihan pangan, obat, dan kosmetika.

\section{B. METODOLOGI PENELITIAN}

Kegiatan ini dilaksanakan pada bulan Agustus hingga Oktober 2018 di Kota Kendari. Metode yang digunakan pada kegiatan pengabdian masyarakat terintegrasi KKN-Tematik ini bertujuan untuk menghasilkan masyarakat muda yang memahami penggunaan obat yang baik dan benar, memahami penggunaan kosmetika yang baik dan benar, memahami pemilihan pangan yang baik dan aman, berperilaku hidup bersih dan sehat, dan mengenal profesi apoteker sebagai tenaga kesehatan.

1. Metode ceramah. Metode ini merupakan metode pembelajaran yang dilakukan dengan cara penuturan atau penjelasan yang disampaikan oleh penyuluh secara lisan. Metode ini digunakan pada kegiatan penyuluhan keamanan pangan, penyuluhan penggunaan obat, penyuluhan penggunaan kosmetika, penyuluhan Gerakan Dapatkan, Gunakan, Simpanlah, dan Buanglah (Dagusibu), penyuluhan Pola Hidup bersih dan Sehat (PHBS), dan penyuluhan sosialisasi apoteker cilik. Metode ini dinilai efektif dalam menyampaikan materi penyuluhan meskipun peran penyuluh lebih dominan dibandingkan peserta. Penyuluh adalah adalah dosen dan mahasiswa yang berkompeten terhadap materi yang dibawakan. Pada berbagai kegiatan di atas, metode ceramah dipadukan dengan metode lainnya yaitu tanya jawab dan latihan.

2. Metode latihan. Metode ini merupakan metode pembelajaran yang dilakukan dengan cara melaksanakan latihanlatihan agar peserta memiliki kemampuan atau keterampilan yang lebih tinggi daripada teori telah 
dipelajari. Metode ini dilakukan pada penyuluhan Pola Hidup bersih dan Sehat (PHBS). Target metode latihan adalah kecakapan motorik dan mental para pelajar.

3. Metode tanya jawab. Metode ini merupakan metode pembelajaran yang dilakukan dengan cara memberikan pertanyaan yang harus dijawab, terutama dari penyuluh kepada para pelajar atau sebaliknya. Metode ini dilakukan pada penyuluhan keamanan pangan, penyuluhan penggunaan obat, penyuluhan penggunaan kosmetika, penyuluhan Gerakan Dapatkan, Gunakan, Simpan, dan Buang (Dagusibu), penyuluhan Pola Hidup bersih dan Sehat (PHBS), dan penyuluhan sosialisasi apoteker cilik.

\section{HASIL DAN PEMBAHASAN}

\section{A. Penyuluhan Keamanan Pangan}

Pengertian pangan menurut Peraturan Pemerintah RI nomor 28 tahun 2004 adalah segala sesuatu yang berasal dari sumber hayati dan air, baik yang diolah maupun yang tidak diolah, yang diperuntukan sebagai makanan atau minuman bagi konsumsi manusia, termasuk bahan tambahan pangan, bahan baku pangan dan bahan lain yang digunakan dalam proses penyiapan, pengolahan, dan atau pembuatan makanan atau minuman (Saparinto C, dan Diana H., 2006)
Pengertian keamanan pangan dalam konteks ini dibagi menjadi dua: keamanan pangan dari segi normatif agama (halal) dan keamanan pangan dari segi kesehatan (toyyib). Dua hal ini sengaja dibedakan karena pada kenyataan ditemukan bahwa aman dari segi normatif agama belum tentu aman secara kesehatan dan begitu sebaliknya aman secara kesehatan belum tentu pula aman menurut agama (Safitri E., 2010).

Peran pangan sangat penting dalam mempertahankan keutuhan suatau bangsa sehingga suatu sistem ketahanan pangan nasional harus diwujudkan. Terjaminnya keamanan pangan bagimasyarakat sesungguhnya bergantung pada peranan dan tanggung jawab pemerintah, khususnya sektor-sektor terkait sebagai fasilisator, pembimbing dan pengawasan, produsen baik produsen bahan baku, industri pangan, distributor, pengecer maupun jasa boga sebagai pelaku utama dan konsumen (Rihastuti dan Soeparno., 2014).

Data World Health Organization (WHO) menyebutkan bahwa penyakit akibat makanan (foodborne disease) dan diare karena cemaran air (waterborne disease) membunuh sekitar 2 juta orang per tahun, termasuk diantaranya anak-anak. Makanan tidak aman ditandai dengan adanya kontaminasi bakteri berbahaya, virus, parasit, atau senyawa kimia menyebabkan lebih dari 200 penyakit, 
mulai dari keracunan makanan, diare sampai dengan kanker. Sementara itu akses terhadap makanan yang bergizi dan aman secara cukup merupakan kunci penting untuk mendukung kehidupan dan menyokong kesehatan yang baik, sehingga keamanan pangan, gizi, dan ketahanan pangan mempunyai hubungan yang tak terpisahkan (Sari MH., 2017).

Sebuah studi baru-baru ini dilakukan oleh Pusat Pengendalian dan Pencegahan Penyakit memperkirakan bahwa setiap tahun di Amerika Serikat, terdapat 47.800.000 penyakit yang disebabkan karena makanan. Hampir 128.000 rawat inap dan sekitar 3.000 orang meninggal. Meskipun angka ini lebih rendah dari perkiraan tahun 1999 (76 juta macam penyakit yang disebabkan oleh pangan dan 5.000 diantaranya mengalami kematian), keamanan pangan tetap menjadi perhatian yang signifikan. Dalam beberapa tahun terakhir, misalnya, terdapat penyakit dalam makanan dan menyebabkan kematian seperti yang disebabkan avian influenza (flu burung) dan virus E.coli pada bayam dan sayuran lainnya, Salmonella enteritidis dalam telur, antraks, cemaran aflataksin pada jagung dan kacang tanah, dan mikroba patogen lainnya (Adiwibowo Y., 2016).

Keamanan pangan merupakan salah satu isu sentral yang berkembang di masyarakat karena semakin meningkatnya kesadaran dan tuntutan masyarakat terhadap makanan yang sehat dan halal. Menyikapi hal tersebut, pemerintah melalui Undang-Undang Pangan No. 18 Tahun 2012, salah satu pasalnya mengatur tentang keamanan pangan. Keamanan pangan diselenggarakan untuk menjaga pangan tetap aman, higienis, bermutu, serta tidak bertentangan dengan agama, keyakinan, dan budaya masyarakat. Keamanan pangan juga dimaksudkan untuk mencegah cemaran biologis dan kimia yang dapat membahayakan kesehatan manusia.

Kegiatan penyuluhan keamanan pangan dilaksanakan di empat sekolah di kota Kendari, yaitu SMA Muhammadiyah Kendari pada tanggal 18 Agustus 2018, SMAN 11 Kendari pada tanggal 13 Agustus 2018, SMKN 6 Kendari pada tanggal 16 Agustus 2018, dan SMK Satria Kendari pada tanggal 15 Agustus 2018. Pentingnya kegiatan penyuluhan keamanan ini yaitu agar pelajar mengetahui pangan yang aman untuk dan memiliki bergizi baik. Serta ciri-ciri pangan yang sudah tidak layak dikonsumsi.

\section{B. Penyuluhan Penggunaan Obat}

Menurut WHO, obat adalah zat yang dapat mempengaruhi aktivitas fisik atau psikis. Sedangkan menurut Kebijakan Obat Nasional (KONAS) ialah bahan atau sediaan yang digunakan untuk mempengaruhi atau menyelidiki system fisiologi dan kondisi patologi dalam rangka 
penetapan diagnosis, pencegahan, penyembuhan, pemulihan rasa sakit, gejala sakit, dan / atau penyakit, untuk meningkatkan kesehatan, dan kontrasepsi (Priyanto dan Batubara, 2008).

Berdasarkan Keputusan Menteri Kesehatan RI Nomor 1027/Menkes/SK/IX/ 2004 tentang Standar Pelayanan Kefarmasian di Apotek, apoteker harus memberikan informasi yang benar, jelas dan mudah dimengerti, akurat, tidak bias, etis, bijaksana, dan terkini kepada pasien di apotek. Informasi obat terhadap pasien sekurang-kurangnya meliputi: cara pemakaian obat, cara penyimpanan obat, jangka waktu pengobatan, aktivitas serta makanan dan minuman yang harus dihindari selama terapi. Apoteker harus memberikan konseling mengenai penggunaan obat dan obat tradisional, sehingga dapat memperbaiki kualitas hidup pasien atau yang bersangkutan terhindar dari bahaya penyalahgunaan atau penggunaan obat yang salah (Supardi S, dkk., 2012).

Obat yang tepat bisa didapatkan atau diperoleh dari sumber resmi seperti Apotek dan toko obat berijin untuk menjamin bahwa obat yang didapatkan bermutu. Sumber resmi yang dimaksud adalah tempat yang memiliki ijin yang dikeluarkan oleh Dinas Kesehatan setempat dan di bawah pengawasan Apoteker yang memiliki surat tanda registrasi apoteker
(STRA) untuk Apotek dan Asisten Apoteker yang memiliki surat tanda registrasi tenaga teknis kefarmasian (STRTTK) untuk Toko Obat berijin.

Berdasarkan peraturan perundangundangan obat terbagi menjadi 4 golongan yaitu: (1) obat bebas dengan logo berwarna hijau dengan lingkaran hitam, dijual di toko/warung, toko obat, apotek; (2) obat bebas terbatas berlogo biru dengan lingkaran hitam, dijual di toko obat, apotek, daftar W; (3) obat keras berlogo merah dengan huruf "K" di bagian tengah dan lingkaran hitam, dengan resep dokter, dijual di apotek, daftar G; dan (4) obat bius dan narkotika berlogo palang merah dengan lingkaran hitam, dengan resep dokter, dijual di apotek, daftar O. Obat-obat bebas dan bebas terbatas dapat diperoleh dari toko obat berijin sedangkan obat keras dan narkotik bisa diperoleh dari apotek dengan resep dokter. (Yati K., dkk., 2018).

Tata cara penggunaan obat yang baik disebut obat yang rasional. WHO menjelaskan definisi dari penggunaan obat rasonal adalah pasien menerima pengobatan sesuai dengan kebutuhan klinisnya, dalam dosis yang sesuai dengan kebutuhan, dalam periode waktu yang sesuai, dan dengan biaya yang terjangkau oleh dirinya dan kebanyakan masyarakat.

Kegiatan penyuluhan penggunaan obat dilaksanakan di empat sekolah di kota Kendari, yaitu SMA Muhammadiyah 
Kendari pada tanggal 18 Agustus 2018, SMAN 11 Kendari pada tanggal 13 Agustus 2018, SMKN 6 Kendari pada tanggal 16 Agustus 2018, dan SMK Satria Kendari pada tanggal 15 Agustus 2018. Pentingnya kegiatan penyuluhan ini agar pelajar mengetahui penggunaan obat dengan baik dan benar serta menghindara penyalahgunaan obat.

\section{Penyuluhan Penggunaan Kosmetika}

Kosmetika adalah bahan atau sediaan yang digunakan pada bagian luar tubuh manusia (epidermis, rambut, kuku, bibir, dan organ genital bagian luar) atau gigi dan membran mukosa mulut terutama untuk membersihkan, mewangikan, mengubah penampilan, dan/atau memperbaiki bau badan atau melindungi atau memelihara tubuh padakondisi baik. Kosmetika saat ini merupakan kebutuhan penting bagi manusia. Kosmetika tidak hanya digunakan untuk fungsi estetika, akan tetapi berperan dalam penyembuhan dan perawatan kulit. Meski bukan merupakan kebutuhan primer, kosmetika merupakan salah satu produk yang digunakan rutin. Oleh karena itu keamanan kosmetika dari bahan-bahan berbahaya perlu diperhatikan (Lisnawati dkk., 2016).

Menurut sifat dan pembuatan kosmetika dibagi menjadi kosmetik modern dan kosmetika tradisional. Kosmetika modern diformulasi dari bahan kimia sintetis dan diolah secara modern.
Kosmetika tradisional diformulasi dari bahan alam dengan pengolahan secara tradisional atau alami dan menggunakan resep warisan secara turun temurun. Industri kosmetika besar banyak mengambil pasar kosmetika modern, sementara kosmetik tradisional oleh industri kecil juga skala rumah tangga (Cahyanto dan Asmawit, 2017).

Kosmetika memiliki efek terhadap kulit yaitu efek negatif dan efek positif. Efek negatifnya bisa disebabkan dari beberapa zat yang terkandung dalamnya yang berbahaya seperti Sodium Lauryl Sulfate (SLS) dan Ammonium Lauryl Sulfate (ALS), bahan pengawet paraben, propilen glikol, isopropyl alcohol, DEA, TEA dan MEA. Sehingga kita harus mengetahui cara memilih kosmetik yang baik dan benar. Adapun langkahlangkahnya adalah sebagai berikut: mengenali jenis kulit dengan tepat, memilih produk kosmetik yang mempunyai nomor registrasi dari Departemen Kesehatan Republik Indonesia, berhati-hati dengan produk yang sangat cepat memberikan hasil, membeli kosmetik secukupnya pada tahap awal, dan memperhatikan keterangan yang tercantum pada label atau kemasan (Pangaribuan, 2017).

Keamanan kosmetika merupakan salah satu topik perbincangan saat ini di kalangan masyarakat. Pria dan wanita menggunakan kosmetika yang 
menyebabkan meningkatnya permintaan konsumen terhadap kosmetika dengan berbagai tujuan. Misalnya produk pemutih kulit yang konsumen menginginkan hasil cepat. Akibatnya banyak oknum pembuat produk yang tidak memiliki izin edar. Menyikapi hal tersebut, pemerintah melalui UU No. 36 tahun 2009 tentang Kesehatan pasal 196 mengatur kebijakan tentang persoalan tersebut. Selain itu, diatur juga dalam Permenkes RI nomor 1176/MENKES/PER/VIII/2010 tentang Notifikasi Kosmetka yang salah satu pasalnya yaitu pasal 3 ayat 1 menyatakn bahwa kosmetika hanya dapat diedarkan setelah mendapat izin edar dari menteri.

Kegiatan penyuluhan penggunaan kosmetika dilaksanakan di empat sekolah di kota Kendari, yaitu SMA Muhammadiyah Kendari pada tanggal 18 Agustus 2018, SMAN 11 Kendari pada tanggal 13 Agustus 2018, SMKN 6 Kendari pada tanggal 16 Agustus 2018, dan SMK Satria Kendari pada tanggal 15 Agustus 2018. Pentingnya kegiatan penyuluhan ini agar pelajar mengetahui bagaimana cara memilih kosmetika yang baik dan zat-zat berbahaya yang terkandung di dalam kosmetika tersebut. Selain itu, juga dapat mengarahkan kepada masyarakat bahwa tidak semua bahan sintetis kimia di dalam kosmetik itu buruk dan tidak semua bahan herbal yang dibuat dalam sediaan kosmetik itu baik. Keduanya memiliki sisi positif dan negatifnya, kecocokan antara keduanya tergantung dari keadaan kulit pengguna.

\section{Sosialisasi Profesi Apoteker}

Apoteker adalah sarjana farmasi yang telah lulus sebagai Apoteker dan telah mengucapkan sumpah jabatan Apoteker. Salah satu peran Apoteker dalam pekerjaan kefarmasian meliputi pelayanan informasi obat (PP 51 tahun 2009). Tugas seorang apoteker salah satunya adalah melaksanakan komunikasi, informasi, dan edukasi tentang obat yang akan digunakan oleh pasien, termasuk di dalamnya melalui poster (Yati dkk., 2018).

Apoteker sangat erat kaitannya dengan apotek, dimana Apotek adalah sarana pelayanan kefarmasian tempat dilakukan praktek kefarmasian oleh apoteker. Sesuai dengan peraturan pemerintah, apotek harus dibawah tanggung jawab seorang apoteker. Keberadaaan apoteker di apotek tidak hanya terkait dengan permasalahan obat, namun apoteker dituntut untuk meningkatkan pengetahuan, keterampilan dan perilaku agar dapat menjalankan profesi secara professional dan berinteraksi langsung dengan pasien, termasuk untuk pemberian informasi obat dan konseling kepada pasien yang membutuhkan. Hal ini bila dikaitkan dengan standar pelayanan kefarmasian di apotek menjadikan peranan apoteker di apotek sangatlah penting (Dominica dkk., 2016). 
Profesi apoteker kurang diakui keberadaannya oleh masyarakat dibandingkan dengan negara lain. Banyak yang mengatakan kesejahteraan apoteker di Indonesia saat ini sangat memprihatinkan dibanding sepuluh tahun yang lalu. Penjelasan tersebut menjadi dasar penting diadakannya brainding profesi apoteker sejak dini terutama di kalangan siswa SD. Apoteker Cilik dibentuk agar eksistensinya dapat dikenal seperti profesi dokter dengan program dokter kecil-nya. Selain itu, untuk meningkatkan kecakapan antar profesi kesehatan dalam harmonisasi profesi agar kedepannya tidak ada perselisihan, menumbuhkan rasa solid dalam bekerja sama serta meningkatkan pengakuan dari masingmasing profesi atas ranah kerjanya (Anidiya dkk., 2013).

Program Apoteker Cilik merupakan sebuah gagasan sebagai upaya dalam membangkitkan eksistensi profesi apoteker secara lebih nyata sejak dini. Hal ini dikarenakan kurangnya pemahaman masyarakat tentang profesi apoteker. Gagasan ini diharapkan dapat meningkatkan citra positif profesi apoteker di masyarakat sehingga tercipta suasana lingkungan yang menyehatkan bagi semua orang.

Kegiatan sosialisasi profesi apoteker dilaksanakan di SDN 02 Baruga pada tanggal 6 Agustus 2018 dan SDN 03 Poasia pada tanggal 11 Agustus 2018. Kegiatan ini bertujuan untuk menanamkan minat kepada murid sekolah dasar tentang kefarmasian dan profesi apoteker.

\section{E. Sosialisasi Gerakan Dagusibu}

Standar Pelayanan Kefarmasian di Apotek, apoteker harus memberikan informasi yang benar, jelas dan mudah dimengerti, akurat, tidak bias, etis, bijaksana, dan terkini kepada pasien di apotek. Informasi obat terhadap pasien sekurang-kurangnya meliputi: cara pemakaian obat, cara penyimpanan obat, jangka waktu pengobatan, aktivitas serta makanan dan minuman yang harus dihindari selama terapi. Apoteker harus memberikan konseling mengenai penggunaan obat dan obat tradisional, sehingga dapat memperbaiki kualitas hidup pasien atau yang bersangkutan terhindar dari bahaya penyalahgunaan atau penggunaan obat yang salah (Supardi S, dkk., 2012).

Apotek harus di bawah tanggung jawab seorang apoteker sesuai dengan peraturan pemerintah,. Keberadaaan apoteker di apotek tidak hanya terkait dengan permasalahan obat, namun apoteker dituntut untuk meningkatkan pengetahuan, keterampilan dan perilaku agar dapat menjalankan profesi secara professional dan berinteraksi langsung dengan pasien, termasuk untuk pemberian informasi obat dan konseling kepada pasien yang membutuhkan. Hal ini bila dikaitkan 
dengan standar pelayanan kefarmasian di apotek menjadikan peranan apoteker di apotek sangatlah penting (Dominica dkk., 2016).

Tugas seorang apoteker salah satunya adalah melaksanakan komunikasi, informasi, dan edukasi tentang obat yang akan digunakan oleh pasien, termasuk di dalamnya melalui poster. Mengingat pentingnya peranan Apoteker dalam menyampaikan informasi obat dan sesuai dengan tujuan IAI dalam mencanangkan Keluarga Sadar Obat (KSO), masyarakat sekitar wilayah kampus perlu mengetahui lebih tentang informasi bagaimana penanganan obat secara tepat. Maka perlu dilakukan sosialisasi tentang Dagusibu Obat. Dengan memberikan pengetahuan tentang pentingnya penanganan obat lewat 'Dagusibu Obat' diharapkan masyarakat mendapatkan pemahaman yang tepat tentang obat dan dapat dihindari penggunasalahan dan penyalahgunaan obat dan pengobatan akan menjadi lebih tepat di masyarakat (Yati dkk., 2018).

Dagusibu adalah langkah penanganan obat sebagai singkatan dari Dapatkan, Gunakan, Simpan, dan Buang. Obat yang tepat bisa didapatkan atau diperoleh dari sumber resmi seperti Apotek dan toko obat berijin untuk menjamin bahwa obat yang didapatkan bermutu. Penggunaan obat yang benar yaitu dengan cara obat-obat yang telah diterima oleh konsumen memiliki aturan penggunaan yang berbeda-beda, petunjuk penggunaan ada di etiket masingmasing obat dan untuk obat bebas terbatas terdapat tambahan peringatan pada kemasan obat. Gunakan obat sesuai dengan petunjuk penggunaan yang terdapat pada kemasan obat. Penyimpanan obat yang baik harus diperhatikan. Obat memiliki stabilitas yang berbeda-beda tergantung dari karakteristik masing-masing bahan obat. Kondisi penyimpanan harus menyesuaikan terhadap stabilitas masing-masing obat. Ada obat yang harus disimpan pada suhu ruang dan ada yang harus disimpan dalam lemari pendingin. Hal selanjutnya yang harus diperhatikan adalah cara membuang obat yang benar. Obat dibuang dengan cara mengeluarkan dari kemasannya kemudian dihancurkan dan dikubur dalam tanah, kecuali untuk obat golongan antibiotik harus dikubur dengan kemasannya (Yati dkk., 2018).

Tugas apoteker adalah menyampaikan informasi obat agar pasien dapat memahaminya. Salah satu metode penyampaian informasi obat adalah Gerakan Dagusibu yang merupakan singkatan dari Dapatkan, Gunakan, Simpan, dan Buang. Melalui program ini masyarakat diharapkan akan memperoleh pemahaman yang tepat tentang obat dan dapat dihindari penggunasalahan dan penyalahgunaan obat dan pengobatan akan menjadi lebih tepat di masyarakat. 
Kegiatan sosialisasi Dagusibu dilaksanakan di SMPN 05 Kendari pada tanggal 15 Agustus 2018. Pentingnya kegiatan penyuluhan Dagusibu agar pelajar mengetahui penggunaan obat dengan baik dan benar.

\section{F. Penyuluhan Perilaku Hidup Bersih dan Sehat (PHBS)}

Perilaku Hidup Bersih dan Sehat adalah sekumpulan perilaku yang dipraktikkan atas dasar kesadaran sebagai hasil pembelajaran yang menjadikan seseorang atau keluarga yang dapat menolong diri sendiri dibidang kesehatan dan berperan aktif dalam mewujudkan derajat kesehatan setinggi-tingginya (Aswadi, dkk., 2017).

PHBS mempunyai 10 indikator, yaitu: 1) Persalinan ditolong oleh tenaga kesehatan; 2) Memberi ASI ekslusif; 3) Menimbang bayi dan balita; 4) Menggunakan air bersih; 5) Mencuci tanga dengan air bersih dan sabun; 6) Menggunakan jamban sehat; 7) Memberantas jentik di rumah; 8) Makan buah dan sayur setiap hari; 9) Melakukan aktivitas fisik setiap hari; 10) Tidak merokok di dalam rumah (Astuti W.D, dkk., 2011).

Gerakan Perilaku Hidup Bersih dan Sehat (PHBS) merupakan ujung tombak untuk pembangunan kesehatan dalam rangka meningkatkan perilaku hidup sehat masyarakat. Program PHBS di Rumah
Tangga merupakan upaya untuk memberdayakan anggota rumah tangga agar tahu, mau dan mampu mempraktikkan perilaku hidup bersih dan sehat serta berperan aktif dalam gerakan kesehatan di masyarakat. PHBS di Rumah Tangga dilakukan untuk mencapai Rumah Tangga berperilaku hidup bersih dan sehat. Perilaku hidup bersih dan sehat seseorang sangat berkaitan dengan peningkatkan kesehatan individu, keluarga, masyarakat dan lingkungannya (Umaroh A.K, dkk., 2016).

PHBS di sekolah adalah upaya untuk memperdayakan siswa, guru, dan masyarakat lingkungan sekolah agar tahu, mau, dan mampu mempraktikkan PHBS dan berperan aktif dalam mewujudkan sekolah sehat. PHBS harus ditanamkan sejak dini agar bisa terbawa hingga usia dewasa. Usia anak sekolah adalah usia yang masih muda, mereka masih membutuhkan bantuan dari orang di sekitar lingkungan terdekat yaitu, orang tua, guru dan teman.Anak usia sekolah merupakan kelompok umur 6-12 tahun yang rawan terhadap masalah kesehatan. Kurang sadarnya masyarakat akan pentingnya PHBS sering menimbulkan masalah kesehatan, seperti Diare, ISPA, penyakit kulit, DHF (Dengue Hemmoragik fever), dan kecacingan. Mencuci tangan secara tepat dengan menggunakan sabun dapat mengurangi resiko penyakit diare sebesar 42 sampai 47\% (Sari N.I, dkk., 2016). 
PHBS adalah semua perilaku kesehatan yang dilakukan atas kesadaran sehingga anggota keluarga dapat menolong dirinya sendiri di bidang kesehatan dan berperan aktif dalam kegiatan-kegiatan kesehatan di masyarakat. PHBS di sekolah adalah upaya pemberdayaan siswa, guru, dan masyarakat lingkungan sekolah agar tahu, mau, dan mampu mempraktekkan PHBS dan berperan aktif dalam mewujudkan sekolah sehat. PHBS harus ditanamkan sejak dini agar bisa terbawa hingga usia dewasa. Usia anak sekolah adalah usia yang masih muda, mereka masih membutuhkan bantuan dari orang di sekitar lingkungan terdekat yaitu, orang tua, guru, dan teman.

Pelaksanaan penyuluhan PHBS dilaksanakan pada tanggal 06 Agustus 2018 di SDN 02 Baruga dan 11 Agustus di SDN 03 Poasia. Pentingnya kegiatan penyuluhan PHBS agar pelajar menerapkan perilaku hidup bersih dan sehat dalam kehidupan sehari-hari.

\section{KESIMPULAN}

1. Penyuluhan keamanan pangan, obat, dan kosmetika telah dilaksanakan di empat SMA/SMK di Kota Kendari.

2. Media leaflet berisi informasi keamanan pangan, obat, dan kosmetika telah sebarkan di empat SMA/SMK di Kota Kendari.
3. Penyuluhan gerakan Dagusibu telah dilaksanakan di satu SMP di Kota Kendari

4. Penyuluhan sosialisasi profesi apoteker dan PHBS telah dilaksanakan di dua SD di Kota Kendari.

\section{DAFTAR PUSTAKA}

Adiwibowo Y., 2016, Epistemologi Ideologi Keamanan Pangan, Yuridika, Vol. 31(1).

Anidya C.A., Azam T., Zhulkifli A. dan Endang S.N, 2013, Acil "Apoteker Cilik": Upaya Membangkitkan Eksistensi Profesi Apoteker dan Sistem Interpersonal EducationProfesi Kesehatan Sejak Dini, Khazanah, Vol. 6(1).

Anwar R.K, Edwin R, dan Encang S., 2015, Kemampuan Literasi Informasi Siswa Tentang Apotek Hidup Berbasis Individual Competence Framework (Studi Terhadap Siswa SMA Di Kota Bandung), Jurnal Kajian Informasi \& Perpustakaan, Vol. 2(1).

Astuti W.D, Zainul K, dan Dewi L., 2011, Perilaku Hidup Bersih Dan Sehat (PHBS) Dalam Rumah Tangga Ibu Hamil Dan Ibu Pernah Hamil Di Indonesia, Buletin Penelitian Sistem Kesehatan, Vol. 14(4)

Aswadi, Sukfitrianty S, Virgilius D, dan Surahmawati, 2017, Perilaku Hidup Bersih Dan Sehat (Phbs) Pada Siswa-Siswi Sdk Rita Pada Kecamatan Kota Komba Kabupaten Manggarai Timur Propinsi Nusa Tenggara Timur, AL- SIHAH, Vol. IX(2).

Cahyanto H.A. dan Asmawit, 2017, Kualitas dan Keamanan Lulur Berbasis Herbal Produksi Ukm Renata di Kota Pontianak, Majalah BIAM, Vol. 13 (02). 
Dominica D., Deddi P.P. dan Yulihasri, 2016, Pengaruh Kehadiran Apoteker Terhadap Pelayanan Kefarmasian di Apotek di Kota Padang, Jurnal Sains Farmasi dan Klinis, Vol. 3 (1).

Lisnawati D., Agustin W. dan Ade P., 2016, Tingkat Pengetahuan Dan Persepsi BahayaKosmetika Yang Mengandung Bahan Pemutih di SMK Negeri 4 Yogyakarta, Media Farmasi, Vol. 13 (1).

Pangaribuan L., 2017, Efek Samping Kosmetik dan Penangananya Bagi Kaum Perempuan, Jurnal Keluarga Sehat Sejahtera, Vol. 15 (30).

Rihastuti dan Soeparno., 2014, Kontrol Kualitas Pangan Hasil Ternak, Gadjah Mada University Press : Yogyakarta.

Safitri E., 2010, Keamanan Pangan Dalam Perspektif Ormas Keagamaan di Indonesia (Studi Kasus di NTB dan Jogjakarta), UNISIA, Vol. XXXIII(73).

Saparinto C, dan Diana H., 2006, Bahan Tambahan Pangan, Penerbit Kanisius : Yogyakarta.

Sari M.H., 2017, Pengetahuan dan Sikap Keamanan Pangan dengan Perilaku Penjaja Makanan Jajanan Anak Sekolah Dasar, Jurnal Of Health Education, Vol. 2(2).

Sari N.I, Bagoes W, dan Aditya K., 2016, Faktor-Faktor Yang Berhubungan
Dengan Perilaku Hidup Bersih Dan Sehat Sebagai Upaya Untuk Pencegahan Penyakit Diare Pada Siswa Di SD N Karangtowo Kecamatan Karangtengah Kabupaten Demak, Jurnal Kesehatan Masyarakat, Vol. 4(3).

Supardi S, Rini S.H, Herman, Raharni, dan Andi L.S., 2012, Kajian Peraturan Perundang-undangan Tentang Pemberian Informasi Obat dan Obat Tradisional di Indonesia, Jurnal Kefarmasian Indonesia, Vol. 2(1).

Umaroh A.K, Heru Y.H, dan Choiri., 2016, Gambaran Perilaku Hidup Bersih Dan Sehat (Phbs) Di Wilayah Kerja Puskesmas Bulu Kabupaten Sukoharjo Bulan Januari-Maret 2015, Jurnal Kesehatan, Vol. 1(1).

Utami P., dan Tim Lentera., 2009, Tanaman Obat untuk Mengatasi Diabetes Mellitus, ARGO Media : Yogyakarta.

Widyawati A.T, dan Muhamad Rizal., 2015, Upaya Pemberdayaan Apotik Hidup Di Perkotaan Melalui Deskripsi Dan Manfaat Tanaman Obat, PROS SEM NAS MASY BIODIV INDON, Vol. 1(8).

Yati K., Hariyanti, Dwitiyanti, dan Pramulani M.L., 2018, Pelatihan Pengelolaan Obat yang Tepat dan Benar di UKS Sekolah-Sekolah Muhammadiyah Wilayah DKI Jakarta, Jurnal SOLMA, Vol. 7(1). 